\title{
Refuge
}

Canada's Journal on Refugees

revue canadienne sur les réfugiés

\section{Examining the Intersection of Race, Gender, Class, and Age on Post-Secondary Education and Career Trajectories of Refugees}

\author{
Jaswant Kaur Bajwa, Mulugeta Abai, Sean Kidd, Sidonia Couto, Aytak \\ Akbari-Dibavar et Kwame McKenzie
}

Volume 34, numéro 2, 2018

URI : https://id.erudit.org/iderudit/1055582ar

DOI : https://doi.org/10.7202/1055582ar

Aller au sommaire du numéro

Éditeur(s)

Centre for Refugee Studies, York University

ISSN

0229-5113 (imprimé)

1920-7336 (numérique)

Découvrir la revue

Citer cet article

Bajwa, J., Abai, M., Kidd, S., Couto, S., Akbari-Dibavar, A. \& McKenzie, K. (2018). Examining the Intersection of Race, Gender, Class, and Age on Post-Secondary Education and Career Trajectories of Refugees. Refuge, 34(2), 113-123.

https://doi.org/10.7202/1055582ar
Résumé de l'article

Cette étude examine, dans une perspective croisée, le rôle des facteurs démographiques sur les parcours d'apprentissage et de carrière de réfugiés au Canada. Elle a consisté à mettre en place un programme unique d'enseignement sur une durée de 14 semaines, qui a été suivi intégralement par un total de 41 réfugiés répartis en deux cohortes, l'objectif étant de surmonter les obstacles, de combler les lacunes, et de favoriser la transition vers l'enseignement supérieur. Les données colligées en suivant un guide d'entretien semi-structuré ont été analysées par une méthode comparative constante. Les résultats laissent penser qu'un modèle d'enseignement qui ofre un soutien créant des conditions propices à la sécurité, au sentiment d'appartenance et à l'autonomisation est déterminant pour lutter contre le racisme, le sexisme et autres facteurs discriminatoires d'origine structurelle, et ainsi favoriser l'accès à l'enseignement supérieur.
Copyright (c) Refuge: Canada’s Journal on Refugees, 2018

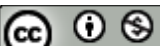

Ce document est protégé par la loi sur le droit d'auteur. L'utilisation des services d'Érudit (y compris la reproduction) est assujettie à sa politique d'utilisation que vous pouvez consulter en ligne. 


\title{
Examining the Intersection of Race, Gender, Class, and Age on Post-Secondary Education and Career Trajectories of Refugees
}

\author{
JASWANT KAUR BAJWA, ${ }^{1}$ MULUGETA ABAI, SEAN KIDD, SIDONIA COUTO, \\ AYTAK AKBARI-DIBAVAR, AND KWAME MCKENZIE
}

\begin{abstract}
This study examines the role of demographics on education and career trajectories of refugees in Canada from an intersectional perspective. It implemented a fourteen-week unique educational program that was completed by forty-one refugees, over two cohorts with the goal to overcome barriers, bridge gaps, and facilitate their transition into higher education. The data collected using a semi-structured interview guide were analyzed using a constant comparative method. The findings suggest that a supportive educational model that promotes safety, sense of belonging, and empowerment are critical to combat the structural racism, sexism, and other discriminatory factors in accessing higher education.
\end{abstract}

\section{Résumé}

Cette étude examine, dans une perspective croisée, le rôle des facteurs démographiques sur les parcours d'apprentissage et de carrière de réfugiés au Canada. Elle a consisté à mettre en place un programme unique d'enseignement sur une durée de 14 semaines, qui a été suivi intégralement par un total de 41 réfugiés répartis en deux cohortes, lobjectif étant de surmonter les obstacles, de combler les lacunes, et de favoriser la transition vers l'enseignement supérieur. Les données colligées en suivant un guide d'entretien semi-structuré ont été analysées par une méthode comparative constante. Les résultats laissent penser qu'un modèle d'enseignement qui offre un soutien créant des conditions propices à la sécurité, au sentiment d'appartenance et à l'autonomisation est déterminant pour lutter contre le racisme, le sexisme et autres facteurs discriminatoires d'origine structurelle, et ainsi favoriser l'accès à l'enseignement supérieur.

\section{Introduction}

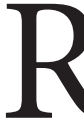
efugees resettled in Canada are provided with services to access housing, medical care, and material supports. However, such civic entitlements do not (c) Jaswant Kaur Bajwa, Mulugeta Abai, Sean Kidd, Sidonia Couto, Aytak Dibavar, and Kwame McKenzie, 2018. This open-access work is licensed under a Creative Commons Attribution-NonCommercial 4.0 International Licence, which permits use, reproduction, and distribution in any medium for non-commercial purposes, provided the original authorship is credited and the original publication in Refuge: Canada's Journal on Refugees is cited.
Cette œuvre en libre accès fait l'objet d'une licence Creative Commons Attribution-NonCommercial 4.0 International License, laquelle autorise l'utilisation, la reproduction et la distribution de l’euvre sur tout support à des fins non commerciales, pourvu que l'auteur ou les auteurs originaux soient mentionnés et que la publication originale dans Refuge: revue canadienne sur les réfugiés soit citée. 
automatically translate to a sense of belonging. ${ }^{2}$ Rather, for resettled refugees, belonging is continuously negotiated through affective encounters with others and intersectional hierarchies within host countries that influence their accessibility to crucial services. ${ }^{3}$ Racial-cultural discrimination and racialization within refugee resettlement policy impose barriers through which the processes of belonging for refugees are hampered. Although refugees face common difficulties during resettlement, their experiences of social inclusion and mobility vary across race, gender, class, ability, and age. Despite attention that has been given to the obstacles they experience in social inclusion, and in accessing careers and education in Canada, an intersectional perspective helps in understanding how gender, race, class, ability, and age affect their integration and access to services. This article considers that the gendered racialization of refugees, in policy and public discourse, affects the everyday experiences of refugees resettled in Canada and are often interwoven with assumptions of deficiency-specifically their career paths and education.

This article focuses primarily on the education and career paths of refugees from an intersectional perspective who have settled in Canada, in order to identify barriers to their advancement. It examines the influence of race, gender, class, and age on post-secondary education and career trajectories of refugees. This research explored the experiences of two separate cohorts of participants who underwent a fourteenweek education program, over two semesters. This innovative education programming was based on the data from the previous phase and was designed to be a preparatory bridging program to support the education and career paths of the refugees. The article sets out to answer three research questions:

1. How can an intersectional analysis help us understand the barriers to refugees in accessing higher education?

2. How do we support racialized and gendered refugees' access to higher education and promote a sense of belonging in them in the process?

3. Does age factor into refugees' quest for post-secondary education and if so, what steps can be taken to mitigate it?

\section{Refugees' Education and Careers in Host Countries}

The right to education for refugees is enshrined in the 1951 Refugee Convention and Human Rights Laws. Education can provide the platform for psychological recovery and healing for refugees. Mariya, Gary, and Gareth argue that "education enables refugees to gain knowledge and skills as well as forging social networks and connections, which are important to find employment and for integration in society." 4 However, despite the crucial role of education in social mobility and inclusion of refugees, only 1 per cent of the worldwide refugee population is able to access higher education, in comparison to 35 per cent of the rest of the population. ${ }^{5}$ Given the importance of higher education for refugees' well-being, healing, and belonging, ${ }^{6}$ it is necessary to understand barriers to refugees' education and social integration in general. 7

One systemic problem in accessing and pursuing higher education for refugees is the lack of documentation or devaluation of their academic credentials from their home countries. According to the Canadian Council of Refugees, "People who are trained within nonwestern educational world views or scientific traditions experience great difficulties in gaining recognition for their training and skills." Consequently, newly arrived refugees might lose motivation, face systemic barriers, and show little or no interest in pursuing their post-secondary education. ${ }^{9}$

The plight of Syrian refugees, for instance, is dire, as the armed conflict saw the massive destruction of infrastructure, leaving many refugees unable to prove their academic credentials and confirm prerequisites required for admissions, even when opportunities for post-secondary education arose. ${ }^{10}$ Although some colleges understand refugees' plight and have provided them alternatives in lieu of actual paper academic records, such recognition is uncommon. ${ }^{11}$

Another challenge to refugees is the financial cost to access post-secondary education. ${ }^{12}$ They can seldom secure financial resources such as scholarships and academic grants, so they are forced to work in low-paying jobs or "survival jobs" in order to finance their higher education..$^{13}$ This problem is also reflected in Canadian colleges and universities, where student enrollment that is considered a mere source of revenue can leave marginalized and impoverished students unable to secure post-secondary education. ${ }^{14}$

It also takes time for refugees to be granted "refugee status," and subsequently, study or work permits. If they do not meet "status" requirements, it is difficult for them to pursue education. Garrette suggests, "Undocumented immigrants and refugees awaiting asylum find it hard to get access to social services. Lacking legal status blocks immigrant and refugee families from seeking assistance.... Instead, they hide and try to become 'invisible' so that they do not run into trouble with the immigration authorities. This, in turn, makes them vulnerable to exploitation and extreme poverty." ${ }^{15}$

Refugees' access and motivation to pursue higher education can be affected by their gender, race, age, and gap in formal education. Jupp and Luckey note that past traumas, life experiences, positionalities, and resettling into a new environment often leave refugees uncertain about their abilities to cope with the education and work options in host 
countries. ${ }^{16}$ Hence refugees need reliable, accurate information and support to navigate their way into post-secondary education, and policies that allow them to overcome social structures that produce inequalities.

It becomes imperative for host countries to develop educational systems, policies, and programs that prepare refugees for post-secondary education. It is also important that the education system take a holistic approach, by creating a sense of belonging among refugees and addressing their identities.

\section{Access to Education from an Intersectional Perspective}

Intersectionality is a term coined by Kimberly Crenshaw, an American civil rights advocate, to highlight the interconnection of social identities and systems of oppression and domination-such as race, class, gender, sexual orientation, ability, and culture-which co-constitute the experience of individuals in society. ${ }^{17}$ Therefore, when analyzing an issue such as class, racial, or gendered barriers to education, one must not relegate the experiences of individuals within an either/or one-category analysis. ${ }^{18}$ Taking a historical perspective, which looks at the interconnections of gender, race, age, and class, and how they affect the re-settlement experience, can help in understanding the barriers to refugees in pursuing a career and education. Furthermore, the refugee resettlement experience cannot be analyzed separately from colonialism, slavery, and war. The difficulties experienced by racialized, gendered, and poor refugees are connected to geo-political, racial, and economic processes. ${ }^{19}$ Therefore, refugee-ness and the knowledge that is produced around refugee-ness should be analyzed intersectionally in policy documents and public discourse, and at the individual level to better understand its impact on career and education during resettlement.

\section{Gender and Race}

Until the 1960s, but persisting through the Bill- $\mathrm{C}_{31}$ amendment to the Immigrant and Refugee Protection Act, 2001, Canadian controls over immigration were racist and discriminatory. ${ }^{20}$ They maintained the interests of the colonial settler society, power structures, and domination of whiteness over other ethno-racial groups. Examples of these laws and practices include the first federal Chinese Exclusion Act in 1885, which imposed a head tax on Chinese immigrants, collecting more than $\$ 22$ million from Chinese immigrants from 1886 to 1923 . The "gentlemen's agreement" between Canada and Japan in 1907 limited emigration of Japanese to Canada to 400 persons a year. Furthermore, "during the Second World War, 22,00o Japanese Canadians were expelled from within a hundred miles of the Pacific, thousands were detained, and at the end of the war, repatriation to Japan was encouraged. 4,00o people left, two thirds of them Canadian citizens." ${ }^{21}$ During the nineteenth and twentieth centuries the immigration of people of African origin was discouraged, including denial of entry to black people in 1911. Furthermore, the labour of black people was officially devalued while Eastern Europeans, viewed as hard workers, were sent to labour-intensive industries such as forestry and mining in Southern Ontario. ${ }^{22}$ Despite the introduction of the point system in 1960, the racist and discriminatory aspects of the previous system are still reinforced through the Immigration and Refugee Protection Act, the Balanced Refugee Reform Act, the Marine Transportation Security Act, and the Department of Citizenship and Immigration Act. ${ }^{23}$ In 2012 the amendment to Bill C-31 allotted new powers to the immigration minister to determine, without council and human right experts deliberation, which countries are deemed "safe" for refugees and immigrants.

Being able to enter Canada does not necessarily translate into belonging and inclusion. Exclusion and inclusion in host countries such as Canada are grounded in a discourse "centered on whiteness as the normative mode of belonging." 24 "Whiteness" is a subjectivity/consciousness that is shared by descendants of European settlers in a settler-colonial land such as Canada and is often represented in the institutions of governance. ${ }^{25}$ European settlers invaded Canada, dispossessed the original inhabitants, and created political institutions that erased indigenous people, their culture, language, and practices. Therefore when examining refugee resettlement we cannot forgo the bias and hierarchy of power that is rooted in its colonial history. These racialized structures define belonging and fuel assumptions of innate difference and deficiency, thus producing and perpetuating discrepancies in wages, unemployment, education, and health. Contemporary immigration policies in Canada are thus similarly designed, demanding that new refugees conform to cultural and linguistic norms of whiteness. ${ }^{26}$ These assumptions of white sovereignty make an intersectional perspective critical and relevant to our understanding.

The OECD/EU shows that the labour market outcomes of specific groups of humanitarian migrants (e.g., the very lowskilled, women, or older refugees) is comparatively low. ${ }^{27}$ Refugee women of colour have significantly worse labour market outcomes, especially in the short to medium run. ${ }^{28}$ Tastsoglou and Preston suggest that "immigrant women are also less likely to participate in the labor market than immigrant men." 29 The sexism and gender stereotypes in the migrant and host culture, in conjunction with a lack of resources, lowered self-esteem, gendered household practices, and lack of familial support may result in women experiencing difficulties accessing higher education or 
coping with the competitive learning environment of postsecondary institutions. Refugee women of colour resettling in Canada may also find themselves caught in the intersection of racism and sexism that promotes assumptions of deficiency, which could reduce their passion, self-esteem, and thus motivation to pursue post-secondary education.

\section{The Age Factor}

Although there has been little research on the effect of age on learning in schools, age can be affect refugees' integration in their new environment. Banerjee and Verma ${ }^{30}$ concluded that "age is known to be negatively related to adults' participation in education." The Organization for Economic Cooperation and Development suggests that older immigrants often experience difficulties in reading, and in particular learning a new language, and that "immigrant students who arrived at the age of 12 or older-and have spent at most four years in their new country-lag farther behind students in the same grade in reading proficiency than immigrants who arrived at younger ages." ${ }^{31}$ Furthermore, Banerjee and Verma discovered that "cognitive ability has been found to diminish somewhat with age, so post-migration education may be more difficult to achieve for older immigrants than younger immigrants." 32 Their finding is corroborated by the Canadian Council for Refugees, which states that older refugees are confronted with learning difficulties and gaps in education. ${ }^{33}$ Older refugee students also often struggle to connect with teachers as the result of language barriers and limited formal or interrupted schooling, and they experience more post-traumatic stress disorder, low self-esteem, and a poor outlook on life, when compared with younger refugee students. ${ }^{34}$ Older refugees are not a homogenous group. Some may be more challenged by lack of language skills, difficulty navigating social services, and greater responsibilities, which may make it difficult for them to pursue education. These issues, coupled with economic needs and family obligations, may keep them in "survivalist" jobs. 35

In addition, age may affect refugees' choice of career path. Pabalinas Jr., Teves, and Teves observe that students' choice of career can be influenced by socio-demographic factors such as age, gender, and parents' occupation. ${ }^{36}$ For instance, older refugees are unlikely to choose careers that involve many years of post-secondary study. Again, as the result of financial constraints, they often opt to combine work with schooling, and hence prefer careers that allow for more flexibility and that are less demanding.

\section{Methods}

\section{Study Design}

This article is based on the data collected within a larger threephase community-based participatory research project that aimed to facilitate refugee survivors' access to higher education. It focuses on the data collected during phase three of the research. Phase one focused on identifying barriers to refugees in accessing higher education. Taking the racialized and gendered experiences of refugees from phase one into account, phase two of the research was spent designing the educational pilot program. And phase three focused on implementing the educational program. The research included two groups of refugees who underwent a fourteen-week program to overcome barriers, bridge gaps, and facilitate their transition into higher education. The data for phase three were collected using a semi-structured interview guide. Questions in the guide were developed by the research steering committee consisting of representatives from the Canadian Centre for Victims of Torture (CCVT), Centre for Addictions and Mental Health (САMH), Wellesley Institute, George Brown College (GBC), and refugees who had experienced trauma. Social workers and service providers were also consulted in the development of the interview questions, to ensure that questions did not retrigger participants' past traumatic experiences. In addition, a trauma-informed, strengths-based, and anti-oppressive perspective was used in interviewing the participants. All participants were interviewed at the entry point, midpoint, and exit point of the pilot program, to gather a sense of their experience throughout the pilot program. The entry point interviews explored participants' educational goals and support needs related to the program. The midpoint and exit point interviews explored participants' perception of the relevance and value of the programming in achieving their educational goals, and whether they had identified changes in themselves as a result of the programming. The exit point interviews also inquired about participants' plans after the program.

\section{Participants}

Forty-one clients responded to a call for participation in the project, completed the fourteen-week program, and provided complete data sets. Two groups of participants attended two sessions of the same program (September to December 2016 and January to April 2017). Participants were provided with allowance to support their travel, refreshments, and resource materials for classes. Participants had to be eighteen years of age or older, had to have completed high school (or an equivalent) and/or some college or university, aspired to pursue post-secondary education, and were survivors of torture and/or war. The study included participants who had no legal status in Canada, as well as those who had gained permanent resident status or even citizenship, because refugee-ness and the experiences of trauma, political oppression, and identity are not erased by legal status, length of time, and years of residency in Canada. These traumas and experiences can become critical parts of refugees' life histories 
Table 1. Demographic information of cohorts

\begin{tabular}{|c|c|c|c|}
\hline $\begin{array}{l}\text { Demographic } \\
\text { information }\end{array}$ & $\begin{array}{c}\text { Cohort } 1 \\
(\%)\end{array}$ & $\begin{array}{c}\text { Cohort } 2 \\
(\%)\end{array}$ & Total (\%) \\
\hline \multicolumn{4}{|l|}{ Age } \\
\hline $18-24$ & $11(57.9)$ & $7(29.2)$ & 18 (41.9) \\
\hline $25-34$ & $4(21.0)$ & $8(33.3)$ & $12(27.9)$ \\
\hline $35-44$ & $1(5.0)$ & $7(29.2)$ & $8(18.6)$ \\
\hline $45+$ & $3(15.8)$ & $2(8.3)$ & $5(11.6)$ \\
\hline \multicolumn{4}{|l|}{ Gender } \\
\hline Men & $6(31.6)$ & $13(54.0)$ & $19(44.0)$ \\
\hline Women & $13(68.4)$ & $11(46.0)$ & $24(55.8)$ \\
\hline \multicolumn{4}{|c|}{ Highest education completed } \\
\hline High school & $13(68.4)$ & $9(37.5)$ & $22(51.2)$ \\
\hline College & $1(5.0)$ & $5(20.8)$ & $6(14.0)$ \\
\hline University & $3(15.8)$ & $10(41.7)$ & $13(54.2)$ \\
\hline Graduate & $2(10.5)$ & & $2(4.7)$ \\
\hline \multicolumn{4}{|l|}{ Country of origin } \\
\hline Africa & $6(31.6)$ & $19(79.2)$ & $25(58.1)$ \\
\hline Asia & $6(31.6)$ & $1(4.2)$ & $7(16.3)$ \\
\hline Middle East & $6(31.6)$ & $4(16.7)$ & $10(23.3)$ \\
\hline Unknown & $1(5.0)$ & & $1(2.3)$ \\
\hline \multicolumn{4}{|l|}{ Time in Canada } \\
\hline Less than 3 months & $1(5.0)$ & $2(8.3)$ & $3(7.0)$ \\
\hline 4-6 months & $3(15.8)$ & $9(37.5)$ & $12(27.9)$ \\
\hline 7-11 months & $6(31.6)$ & $3(12.5)$ & 9 (20.9) \\
\hline $1-6$ years & $6(31.6)$ & $8(33.3)$ & $14(32.6)$ \\
\hline 6 years + & $2(10.5)$ & $1(4.2)$ & $3(7.0)$ \\
\hline Unknown & $1(5.0)$ & $1(4.2)$ & $2(4.7)$ \\
\hline \multicolumn{4}{|l|}{ Status } \\
\hline Refugee claimant & $6(31.6)$ & $13(54.2)$ & $19(44.2)$ \\
\hline Conventional refugee & $1(5.0)$ & $3(12.5)$ & $4(9.3)$ \\
\hline Permanent resident & $7(36.8)$ & $4(16.7)$ & $11(25.6)$ \\
\hline Canadian citizen & $2(10.5)$ & $1(4.2)$ & $3(7.0)$ \\
\hline Other & $1(5.0)$ & $2(8.3)$ & $3(7.0)$ \\
\hline Unknown & $2(10.5)$ & $1(4.2)$ & $3(7.0)$ \\
\hline
\end{tabular}

and reference points for their life stories, and these narratives and identities as survivors continue, despite changes in status or temporality. Most participants were referred from CCVT, as they are the only agency in Toronto that provides holistic specialized services for refugee survivors of torture and/or war. However, some participants were referred to
CCVT by other refugee-serving community agencies. CCVT receives referrals from other resettlement organizations who advance refugee housing, language, employment, and other life conditions but may not have the expertise to work with trauma survivors. Therefore CCVT clientele represent refugees who are trauma survivors, have settled in the Greater Toronto Area, are experiencing difficulties in adjusting to life in Canada, and want to pursue higher education. Table 1 presents an overview of participants' demographic information.

\section{Data Analysis}

One-on-one interviews with participants were recorded and transcribed for analysis using open coding to detect emergent dimensions. Research assistants and members of the investigator team then coded overlapping subsets of the data to generate a preliminary codebook that was refined through group discussions and review of the transcripts. Transcripts were coded utilizing the codebook agreed upon by the group, and subsequent axial coding allowed for the induction and deduction of themes based on the codes as well as identification of patterns and categories evident in the data. Finally, analytic memos were utilized throughout the analysis. ${ }^{37}$ A data-analysis program called NVivo 11 was used with the coding of the transcripts.

\section{Design of the Educational Pilot}

The educational pilot program utilized anti-oppressive principles (AOP). An anti-oppressive framework is aware of the power dynamics in the educational system that determine participants' experiences and are linked to historical and structural injustices. It is based on the premise that oppression is the use of power to disempower, marginalize, silence, or subordinate one social group or category, often to further empower and/or privilege the oppressor. This practice seeks to recognize oppression in our society, mitigate its effects, and equalize the power imbalance in our communities. Thus the education program piloted in this research uses an inclusive and strength-based perspective. ${ }^{8}$ The program's content and method of instruction considered the structural, economic, racial, social, and gendered disadvantages faced by refugees, and addressed their loneliness, loss of social support, lack of access, and sense of exclusion. Program facilitators and researchers adjusted to the content and methods of instruction used in the classroom to cater to the needs of the most marginalized participants, often the older women of colour. Efforts were made to create a safe space for participants who had difficulty speaking up or engaging in a classroom.

The pilot program received support from resettlement agencies (e.g., advocacy, legal support, language or career training); however, it was still unique in Canada because it went beyond them in its focus to facilitate participants' 
Table 2. Test of within and between subjects effect for self-esteem by age

\begin{tabular}{|c|c|c|c|c|c|c|}
\hline & & SS & $d f$ & MS & $F$ & $p$ \\
\hline \multirow{2}{*}{ Entry } & Within groups & 791.339 & 37 & 21.388 & & \\
\hline & Total & 917.220 & 40 & & & \\
\hline Midpoint & Between groups & 106.532 & 3 & 35.511 & 1.491 & .233 \\
\hline \multirow[t]{3}{*}{ Exit } & Between groups & 80.821 & 3 & 26.940 & 1.329 & .280 \\
\hline & Within groups & 750.057 & 37 & 20.272 & & \\
\hline & Total & 830.878 & 40 & & & \\
\hline
\end{tabular}

Table 3. Test of within and between subjects effect for self-esteem by gender

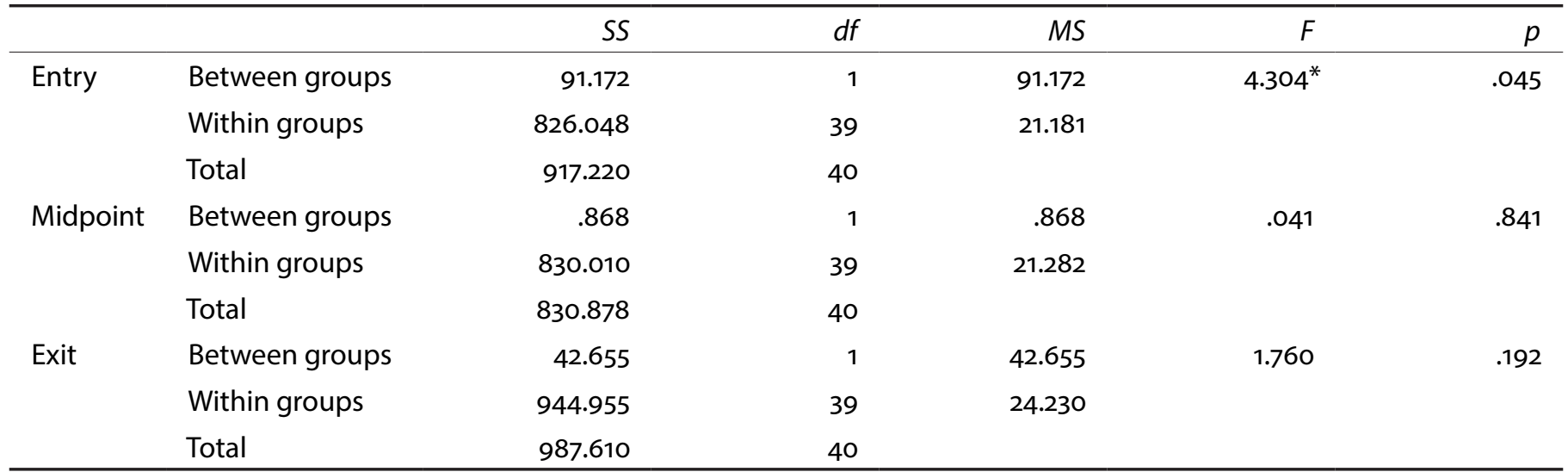

*The result is significant at $p<.05$

access to higher education, so it laid the groundwork for other resettlement agencies. 39

\section{Results}

In table 2, results of ANOvA indicate that age was not statistically significant in self-esteem of the participants between the groups and within the groups. Table 3 shows that women had lower self-esteem that was statistically significant in comparison to men at the entry point, but there were no differences between men and women at the end of the program.

Analysis of the qualitative data from the interviews revealed their experiences, their struggles, and what they found helpful, useful, or most beneficial.

\section{Knowledge Is Power: Recognizing Systemic Oppressions}

The pilot program provided participants with awareness and knowledge to match power, oppression, and powerlessness to their own experiences. This understanding allowed them to experience a transformation in the relationship between their assessment of a situation, their personal experiences, and the action they need to take. Ms. HJ, who was experiencing racism and discrimination, stated, "I wish I knew this earlier, that even as a refugee I had rights. Nobody can make me not eat with others because I am a woman and I am black."

On being asked if they noticed changes in themselves that were barriers to their goals, thirty-nine out of fortyone participants answered "yes" and only two mentioned "no." When asked, "Has the program helped you to understand how to pursue and achieve your educational goals and address systemic challenges?," thirty-eight of forty-one participants answered a clear "yes." In addition, 6o per cent of participants stated that their plans had evolved, they felt more prepared to reach their goals with the new knowledge of navigating the education system and assessing situations, 
advocating for themselves, looking for allies, and accessing supports and resources they needed to reach their goals. As one participant reflected, the program has made her feel good about herself, as well as her communication and social skills: "I started communicating with people and smiling to strangers [laughs]. My networking has improved. Before I had only three friends, but now I have many. I learnt more about myself, that I am more interactive. My self-esteem is higher now, and I can confidently ask for what I need, though I still get nervous sometimes with people and situations, but I now know what I need to do."

Participants were highly satisfied with the program. It gave them clarity on what they wanted to pursue. This clarity increased motivation and confidence, which was attributed to new knowledge on how to access supports and overcome systemic hurdles. Participants reported that they noticed positive changes in themselves and saw themselves as more "confident and self-motivated":

I've become [a] more positive [person]. The program matured me in a sense that [I've come to] know my learning abilities. I've come to know that there are many beautiful things deep inside me that I can unleash and live a very productive life.

At the beginning of the program ... I was not sure what route to take, how to take, deal with so many problems ... but the program [has] enabled me to focus, to believe in [studying] human rights is realistic. If it [wasn't for] this program, I would never be at George Brown College. So, [now] I feel I can go to school, I can pursue my career, I can do much more.... I am actually so inspired. And I intend to focus on human rights.... Because I feel I've gone through what other refugees are going through; and I can support them.... I know how to stand [up] for them. So I think I'm in a better position of advocacy now.

\section{Exploring Personal Experiences}

The program included activities on racism and discrimination such as case studies, scenarios, and role playing, which allowed participants to engage with the issues and find their relevance to their own lives. Participants shared personal accounts of racism and discrimination, its impact on them, their reactions, and how they would address both in the future. As Ms. KH mentioned, "I found everyone [who was] running this program to be very nice, caring, and supportive. They were understanding of my situation with regards to racism. They supported me, advocated for me, taught me how to advocate, and were there for me when I needed them."

\section{Understanding Power and Personal Social Location}

Thirty-nine of forty-one participants indicated that they had gained awareness and knowledge about power as a social concept, how to place personal experiences within the larger social context and the role of social differences, and disparities of power between the social groups in race, gender, class, sexual orientation, disability, and age. They reflected on other differences such as religion, mental health, and single parenthood, etc. The program had helped them to apply this understanding to the Canadian educational system, helped them to identify potential resources, and enabled them to navigate the systems in Canada and to deal with challenges. One participant stated, "I am able to see my place in the larger Canadian context and understand what I am going through."

\section{Empowerment through Strength-Based Self-Discovery}

The educational program offered activities to explore self and career, which included opportunities to examine personality dimensions, multiple intelligences, career navigation skills, and learning styles. These activities allowed participants to understand themselves, recognize their strengths and passions, and discover the best way they learn. The responses from most participants, irrespective of their backgrounds, suggested that their confidence and hope for the future had improved since they started the program. Some participants expressed optimism about conflict ending in their home country and hoped that one day they may be able to return to their country of origin, once peace returns. They expressed an interest in acquiring post-secondary education in Canada so that they could use this knowledge and skill in their country of origin, to help victims of torture, discrimination, and human rights abuse. Ms. AA responded, "I am now clear on the career I want to pursue. It's nursing. I am 100 per cent sure I want to study nursing. It will be useful if I go back to my country eventually. If I return to my country, I will be useful."

\section{Role of Safe Learning Environment in Creating Hope for the Future}

With a greater awareness of their strengths in a supportive learning environment, participants gained clarity on their goals and ways to navigate and address systemic challenges. The program enabled them to explore their past while recognizing their potential and provided them with skills to navigate the system, which elevated their self-esteem. As suggested by Herbert, combating apathy or aversion develops consistent hopefulness and optimism. ${ }^{40}$ According to one participant, Ms. YA, "I feel good about myself. I like education. I was in high school but could not grab things. But this program has helped me. I left school. Also my marital problems all had a huge impact on me. Now I am eager to learn and have a future." 


\section{Discussion}

How can an intersectional analysis help us understand the barriers faced by refugees in accessing higher education?

An intersectional perspective was critical in identifying barriers to refugees that were rooted in patriarchal gender relations in Canada and their home countries, which create a racialized and gendered refugee subject, who is either seen as passive and needy, or dangerous and needs to be securitized. ${ }^{41}$ In addition, racism and patriarchy tend to create gendered and racialized representations of refugee women, which lead to isolation and "othering" in the host society, devaluing them and their labour. Such representations silence and erase refugees, diminish their self-confidence and sense of self-worth, likely making them feel insecure in accessing post-secondary education or achieving life goals. As a result, it may become harder for them to find the courage to pursue higher education without external supports.

Incorporating an intersectional perspective during phases one and two of this research allowed us to develop an educational program that was considerate and relevant to participants' needs. Participants discussed their experiences of racialized and sexualized violence, and the program created a non-judgmental, safe, and inclusive environment for those experiences to be acknowledged, validated, and explored. This promoted a sense of belonging, empowered them, and supported their self-worth and self-esteem, allowing them to build resilience, tap into their own internal agency, and navigate discrimination and racism within Canada. They also learned not to internalize these experiences. In addition, the program utilized the expertise of counsellors from CCVT who understood the impact of traumatic experiences on participants' learning, world view, and hopefulness. In the safety of the program, participants were able to redefine identity and not feel helpless or hopeless. This is an important change, as students who lack confidence in their ability to succeed may also lack willingness to engage in their courses or programs. ${ }^{42}$ Feelings of intimidation and inadequacy may prohibit them from fully participating. ${ }^{43}$ However, if students sense that their instructors care, this can increase levels of engagement, student success, and retention. ${ }^{44}$

How do we support racialized and gendered refugees' access higher education and promote a sense of belonging in them in the process?

Personal connections and supports in education can result in better outcomes for impoverished racialized women in general, and refugees in particular. 45 The pilot program offered a safe space and support for healthy relationships to form, trust to develop, personal connections to be forged, and sense of belonging to be felt among participants and with the research team and facilitators as well. A new sense of belonging to a legitimate (i.e., non-marginal, stigmatized) community grew, and the impact of being "othered" and feelings of not being cared for were diminished. Fleeing to safety does not necessarily reduce stress for refugees. ${ }^{46}$ They may carry residue of their past that may debilitate their ability to move forward. The positive space created conditions for healing from these traumatic experiences, tangibly enhancing selfesteem, improving communication skills, and motivating them to pursue their higher educational goals: 98 per cent of participants are pursuing higher educational programs to further their career goals.

Using an AOP framework, the research team and program facilitators modelled their socially constructed perceptions, recognized power imbalances, and worked to redress the balance of power. 47 Their effort created inclusiveness for the students and a sense of belonging. Participants spoke about the way instructors responded and made them feel when they checked in with them about events in their lives, their feelings, and their needs. It can be deduced that these conditions were essential in their pursuit of post-secondary education.

Is age relevant in refugees' quest for post-secondary education, and if so, what can mitigate its impact?

Age was an important factor in participants' quest for postsecondary education. Although all participants aspired to return to college or university, older participants struggled against legal status in Canada, lack of recognition of their credentials, lack of language training, and financial concerns. They also had lower self-esteem when they started the program in comparison to the younger refugees. Although the programming improved self-esteem for all participants, there were no substantial changes in self-esteem by age. Older refugees were under greater financial strain, performed multiple roles, and were more vulnerable to compromising their career and educational goals in favour of their responsibilities. They were also at greater risk for exploitation and harassment by landlords and employers, due to language barriers, lack of understanding of the system, and difficulty accessing resources. During the pilot program, both older and younger participants became more open to the idea that it is never too late to attend school, build confidence, become hopeful for the future, and improve their community participation. Overall, the program made them more determined and energized. Nevertheless there was hesitation to pursue this option of post-secondary education without fully understanding the financial burdens it would put on them or their dependents. Older participants were also more concerned about their ability to learn English. The findings are supported by Banerjee and Verma, who suggest 
there is a negative relationship between age at migration and post-migration education. ${ }^{48}$ They stated, "Immigrants arriving early in their careers may have lower opportunity costs and greater incentive to invest in higher education." The older participants' confidence was also shaken by not being able to understand and communicate well, not having the necessary documentation, and not having the support to guide them to access grants, bursaries, and other means of financial support.

\section{Conclusion}

This research expands on previous work on anti-oppressive pedagogy using an intersectional lens and describes innovative programming to support educational decisions of refugees in Canada who have survived trauma and political violence. This research outlines systemic complexities-not limited to race, gender, and age - that need to be addressed in any policies. The study also highlights the importance of education, which improves life outcomes and is a tool for empowerment and a means for social inclusion for marginalized communities. Ontario's publicly funded education system needs to be fairer and more inclusive for all students, regardless of race, religion, ethnicity, gender, age, legal status, or any other factor related to individual identity that gives them an opportunity to succeed. Refugees experience systemic discrimination that thwarts their attempts to reach their full potential and pushes them to the margins of society. Refugees face unique challenges and require understanding, flexibility, and accommodation to improve to their opportunities. This research offered a unique program that used an anti-oppressive framework and an intersectional lens, created conditions to bridge the gap in education and career paths for refugees and promote social integration. The findings suggest that a supportive educational model that promotes self-esteem and a sense of belonging is critical to combat the structural, financial, and intersectional factors that restrict access to higher education and the pursuit of educational-career goals.

\section{Notes}

1 I would like to thank the guest editors, editors, and anonymous reviewers for their comments and suggestions. A very special thanks goes also to Social Science Humanities Research Council for their funding for this research project.

2 Farida Fozdar and Lisa Hartley, "Civic and Ethno Belonging among Recent Refugees to Australia," Journal of Refugee Studies 27, no. 1 (2013): 126-44.

3 Melanie Baak, "Murder, Community Talk, and Belonging: An Exploration of Sudanese Community Responses to Murder in Australia," African Identities 9, no. 4 (2011): $417-34$.

4 Shisheva Mariya, Christie Gary, and Mulvey Gareth, Improving the Lives of Refugees in Scotland after the Referendum: An Appraisal of the Options (Glasgow: Scottish Refugee Council, 2013).

5 See United Nations High Commissioner for Refugees, Missing Out: Refugee Education in Crisis (Geneva: UNHCR, 2016).

6 Government of Manitoba, Life after War: Education as a Healing Process for Refugee and War-Affected Children (Winnipeg: Manitoba Education, 2012).

7 Yatta Kanu, "Educational Needs and Barriers for African Refugee Students in Manitoba," Canadian Journal of Education 31, no. 4 (2008): 915-40.

8 Canadian Council for Refugees, Report on Systemic Racism and Discrimination in Canadian Refugee and Immigration Policies, 2000, http://ccrweb.ca/files/arreport.pdf.

9 Janet Hannah, "Refugee Students at College and University: Improving Access and Support," International Review of Education 45, no. 2 (1999): 153-66.

10 Dominique Bonessi, "The Shattered Pieces of a War-Torn Education," Atlantic, 12 October, 2016.

11 See World University Service of Canada, The Canadian Post-secondary Education Community's Response to the Refugee Crisis (Ottawa: wuCs, 2016), http://assets.wusc .ca/wuscwebsite/reportsandfinancials/reportsandpublications/wUSC_roundtable_discussion_w_recommendations_02.pdf.

12 Xulien Zhang and Boris Palameta, "Participation in Adult Schooling and Its Earnings Impact in Canada," Analytical Studies Branch Research Paper 276 (Ottawa: Statistics Canada, 2006).

13 Jenny Francis, You Cannot Settle Like This: The Housing Situation of African Refugees in Metro Vancouver (Vancouver, BC: Metropolis British Columbia, 2009), 36; Denise L. Spitzer, Engendering Migrant Health: Canadian Perspectives (Toronto: University of Toronto Press, 2011).

14 Olivia Bako, "Neoliberalism and Its Effect on Canadian Women in Poverty," Lyceum 1, no. 1 (2011): 32-40.

15 Katherine Garrette, Living in America: Challenges Facing New Immigrants and Refugees (New Jersey: Robert Wood Johnson Foundation, 2006).

16 J.J. Jupp and J. Luckey, "Educational Experiences in Australia of Indo-Chinese Adolescent Refugees," International Journal of Mental Health, 18, no. 4 (1990): 78-91.

17 Kimberly Crenshaw, "Mapping the Margins: Intersectionality, Identity Politics, and Violence against Women of Color," Stanford Law Review 43 (1990): 1241-99.

18 Crenshaw, "Mapping the Margins."

19 Gita Chowdhry and Sheila Nair, Power, Postcolonialism, and International Relations: Reading Race, Gender, and Class (London: Routledge, 2002). 
20 See Canadian Council for Refugees, Refugee Integration: Key Concerns and Areas for Further Research (Montreal: CCR, 2011).

21 See CCR, Report on Systemic Racism, 2.

22 Robin W. Winks, The Blacks in Canada: A History (Montreal and Kingston: McGill-Queen's University Press, 1997).

23 Winks, Blacks in Canada.

24 Clemence Due, “'Who Are Strangers?' Absorbing Sudanese Refugees into a White Australia," ACRWSA 4, no. 1 (2008): $1-13$.

25 Sara Ahmed, "A Phenomenology of Whiteness," Feminist Theory 8, no. 2 (2007): 149-68.

26 Finex Ndhlovu, "Post-Refugee African Australians' Perceptions about Being and Becoming Australian: Language, Discourse, and Participation," African Identities 9, no. 4 (2011): 435-53.

27 See Organization for Economic Co-operation and Development, Helping Immigrant Students to Succeed-and Beyond (Pisa: OECD, 2015).

28 Regina Konle-Seidl and Georg Bolits, Labor Market Integration: Strategies and Good Practices (Brussels: European Union, 2016); Ranu Basu, "The Rationalization of Neoliberalism in Ontario's Public Education System, 1995-2000," Geoforum 35, no. 5 (2004): 621-34.

29 Evangelia Tastsoglou and Valerie Preston, "Gender, Immigration and Labour Market Integration: Where We Are and What We Still Need to Know," Atlantis 30, no. 1 (2005): 46-59.

30 Rupa Banerjee and Anil Verma, "Determinants and Effects of Post-Migration Education among New Immigrants in Canada," Canadian Labour Market and Skills Researcher Network, 2009. See also Andrew Jenkins, Anna Vignoles, Alison Wolf, and Fernando Galindo-Rueda, "The Determinants and Effects of Lifelong Learning," Applied Economics 35, no. 16 (2003): 1711-21.

31 See oecD, Helping Immigrant Students to Succeed.

32 Banerjee and Verma, "Determinants and Effects of PostMigration Education."

33 CCR, Refugee Integration.

34 Rabia Hos, “The Experiences of Refugee Students with Interrupted Formal Education in an Urban Secondary School Newcomer Program" (PhD diss., University of Rochester, 2012).

35 Erhard Berner, Georgina Mercedes Gómez, and Peter Knorringa, Helping a Large Number of People Become a Little Less Poor ( The Hague: Institute of Social Studies, Erasmus University Rotterdam, 2009).

36 Saturnino Pabalinas Jr., Aldwin Teves, and Keran luz Teves, "Career Choice: An Analysis of Multiple Intelligence and Social Environmental Factors," International Conference on Trends in Economics, Humanities and Management, 27-8 March 2015, Singapore, http://icehm.org/ upload/2466ED0315092.pdf, 81-3.
37 Melanie Birks, Ysanne Chapman, Karen Francis, "Memoing in Qualitative Research: Probing Data and Processes," Journal of Research in Nursing 13, no. 1 (2008): 68-75.

38 Please see our upcoming paper on the findings from phase one of our research.

39 The exact dynamic and schedule of the classrooms are explored in another paper that is under peer review.

40 Marthine Herbert, "An Exploration of the Relationships between Psychological Capital (Hope, Optimism, Selfefficacy, Resilience), Occupational Stress, Burnout and Employee Engagement" (MA thesis, University of Stellenbosch, South Africa, 2012).

41 See Partha DasGupta, "A Matter of Trust: Social Capital and Economic Development" (paper presented at the Annual Bank Conference on Development Economics, Seoul, June 2009); also see Lamia Ben Youssef Zayzafoon, The Production of the Muslim Woman: Negotiating Text, History, and Ideology (Minneapolis, MN: Lexington Books, 2005).

42 Garrette, Living in America.

43 Jupp and Luckey, "Educational Experiences in Australia."

44 Hannah, "Refugee Students at College and University"; Maurice Badibanga, "Educational Opportunities for Refugee Women and Girls in Zimbabwe: A Case Study of Refugee Women and Girls of the Democratic Republic of Congo" (MA thesis, University of Zimbabwe, 2006).

45 Jenny Horsman, Too Scared to Learn: Women, Violence and Education (New Jersey: Lawrence Erlbaum Associates, 1999/2000). See also Georgia Quartaro, Jenny Horsman, Jaswant Kaur Bajwa, Anna Willats, and Mandy Bonisteel, Marginalized Women and Apprenticeship Training: Investigating a High Support Model (Toronto: George Brown College, 2009).

46 See UnHCR, Missing Out; Fredrick Lindencrona, Solvig Ekblad, and Edvard Hauff, "Mental Health of Recently Resettled Refugees from the Middle East in Sweden: The Impact of Pre-Resettlement Trauma, Resettlement Stress and Capacity to Handle Stress," Social Psychiatry and Psychiatric Epidemiology 43, no. 2 (2008): 121-31.

47 Jane Dalrymple and Beverly Burke, Anti-Oppressive Practice: Social Care and the Law (Buckingham, uk: Open University Press, 1995).

48 Banerjee and Verma, "Determinants and Effects of PostMigration Education.”

Jaswant Kaur Bajwa is a professor and research lead in the Centre for Preparatory \& Liberal Studies at George Brown College. She is also principle investigator for the SSHRC-funded project titled "From Margins to Centre through Education: Integrating Victims of Trauma and Torture." The author may be contacted at jkaur@georgebrown.ca.

Sean Kidd is a clinical psychologist and clinician scientist at the Centre for Addiction and Mental Health. The author can becontacted at sean.kidd@camh.ca. 
Mulugeta Abai is the executive director of the Canadian Centre for Victims of Torture. The author can be reached at mabai@ccvt.org.

Sidonia Couto is an registered social worker who worked with the Canadian Centre for Victims of Torture at the time of this research. The author can be contacted at sidonia_o1@hotmail .com.
Aytak Akbari-Dibavar is a PhD candidate at York University and research coordinator for this research project. The author can be contacted ataytakd@gmail.com.

Kwame McKenzie is the CEO of the Wellesley Institute and a psychiatrist with the Centre for Addiction and Mental Health. The author can be reached at kwame@wellesleyinstitute.com. 